\title{
EVOLUTION OF BARRIERS TO CROSSING OF SELF-INCOM- PATIBLE WITH SELF-COMPATIBLE SPECIES OF SOLANUM
}

\author{
PAUL GRUN and ANNE RADLOW \\ Department of Botany and Plant Pathology *, Pennsylvania State \\ University, University Park, Pennsylvania
}

\section{INTRODUCTION}

ATtempts that have been made to cross a number of self-incompatible plant species with their self-compatible relatives have lead to the conclusion that in some cases the cross can be made only when the self-compatible species is used as the female. When the self-compatible parent is used as male the pollen tube fails to grow down the style of the self-incompatible pistillate parent. The most thoroughly documented examples of this phenomenon have been recorded for species of Nicotiana (Anderson and DeWinton, 1931), Petunia (Mather, 1943), Lycopersicon (McGuire and Rick, 1954), Solanum (Garde, 1959) and Antirrhinum (Harrison and Darby, 1955), species occurring in the related families Solanacee and Scrophulariacee. In addition, intergeneric crosses between members of the Solanacee and even inter-family crosses between members of the two families have been found to show this oneway crossing inhibition (Lewis and Crowe, 1958).

Numerous exceptions to the pattern are known in the form of successful self-incompatible $\times$ self-compatible crosses. Examples can be cited in, among other genera, Lycium (Lewis and Crowe, 1958), Antirrhinum (Harrison and Darby, 1955), Papaver (Fabergé, 1944), Nicotiana (East, 1919), Brassica (Kakizaki, 1930), Layia (Clausen, 1951), and Potentilla (Clausen and Hiesey, 1958). It has been hypothesised by Lewis and Crowe (1958) that the self-compatible parent is, in these cases, of recent origin, in its general genetic make-up is closer to the self-incompatible than the self-compatible group, and so in its crossing behaviour acts as a self-incompatible form.

Since the failure of the self-incompatible $\times$ self-compatible crosses may constitute a basic mechanism contributing to species isolation, it is important to determine how widespread it is in occurrence, and the nature of exceptions to its operation. The present study is an analysis of cross-ability of self-incompatible with self-compatible species of Solanum. In the course of this work, an example of reciprocal crossability between the two types was found that cannot be readily interpreted as resulting from a recent evolution of the self-compatible species from a self-incompatible progenitor.

In this analysis self-incompatible species of the series Tuberosa

* Paper number 264 from the Department of Botany and Plant Pathology, The Pennsylvania State University. This study was supported by a grant from the National Science Foundation. 
and Commersoniana were crossed with clones of the self-compatible species $S$. verrucosum of the series Demissa. While the genetic mechanism responsible for self-incompatibility has not been determined for all of the species used, it has been established (Pal and Nath, 1942; Nath, I 942 , I 945) that some members of the Commersoniana have oppositional alleles of the Nicotiana type. Recent evidence has been produced (Garde, 1959) showing that one-way isolation does occur between $S$. verrucosum and some members of the Tuberosa, although the cross $S$. chaccense and $S$. phureja $\times S$. verrucosum has been accomplished (Buck, I96o).

\section{MATERIALS AND METHODS}

Diploid species of Solanum of the section Tuberarium were used in the experiment. In the preliminary $1956-58$ crosses listed in table 1 , flowers were emasculated and

TABLE ,

Results of preliminary crossings between diverse species of Solanum and S. Verrucosum

\begin{tabular}{|c|c|c|c|c|c|}
\hline \multirow{3}{*}{\multicolumn{2}{|c|}{$\begin{array}{l}\text { Self-incompatible } \\
\text { species }\end{array}$}} & \multicolumn{4}{|c|}{ Self-compatible $S$. verrucosum used as } \\
\hline & & \multicolumn{2}{|c|}{ Pistillate parent } & \multicolumn{2}{|c|}{ Pollen parent } \\
\hline & & $\begin{array}{l}\text { No. } \\
\text { pollinations }\end{array}$ & $\begin{array}{l}\text { Berries } \\
\text { set }\end{array}$ & $\begin{array}{l}\text { No. } \\
\text { pollinations }\end{array}$ & $\begin{array}{c}\text { Berries } \\
\text { set }\end{array}$ \\
\hline \multicolumn{6}{|l|}{ Series Commersoniana } \\
\hline S. chacernse & . & 26 & 14 & 26 & 11 \\
\hline S. chaccense spp. subtilius & . & $5 \mathrm{t}$ & 25 & 69 & I \\
\hline S. kurtzianum & & 6 & 2 & 13 & o \\
\hline S. tarijense & . & 5 & 1 & 8 & o \\
\hline \multicolumn{6}{|l|}{ Series Tuberosa } \\
\hline S. phureja & . & 19 & 2 & 19 & o \\
\hline S. stenotomum & . & 34 & 12 & 36 & 0 \\
\hline S. soukupii & . & 15 & 3 & 7 & o \\
\hline S. simplicifolium & . & 15 & 6 & 23 & o \\
\hline S. neohawkesii . & . & 13 & 8 & 6 & o \\
\hline S. sparsipilum & . & 9 & 2 & 4 & o \\
\hline
\end{tabular}

pollinated at a late bud stage and protected from insect visit by the use of pieces of soda straw having an inner diameter of $8 \mathrm{~mm}$. The species used for the 1959 crossings are listed in table 2 with their U.S. Department of Agriculture accession numbers and places of origin. For the 1959 crosses, flowers were emasculated in a late bud stage, allowed to open inside a cheesecloth bag, pollinated when open, and then covered again with the cheesecloth bag. This was done to eliminate the possibility that berry set could occur because pollinations were at a bud stage instead of on open flowers. All crossings were carried out in the greenhouse during winter and sprin gmonths under relatively constant environmental conditions.

\section{RESULTS}

Berry sets following preliminary reciprocal crossings between $S$. verrucosum and a number of species of the series Tuberosa and Commersoniana are listed in table I. Berries were set when self-compatible 
S. verrucosum was the pistillate parent, but the reciprocal crosses usually failed. This was in agreement with the model described above.

The successes of reciprocal crosses between $S$. verrucosum on the one hand and $S$. chaccense and $S$. chaccense ssp. subtilius on the other, however, disagree with the model. As a check against the possibility that pollen other than that of $S$. verrucosum had been used, some of the seeds of the $S$. chaccense $\times$ verrucosum berries were germinated. The plants produced thereby were fertile $F_{1}$ hybrids whose morphology confirmed their identity. The most likely interpretation of the success of this cross seemed to be that different clones of $S$. chaccense differ in their selfincompatibility, and that in those cases in which $S$. chaccense styles

TABLE 2

Identity and place of origin of clones used

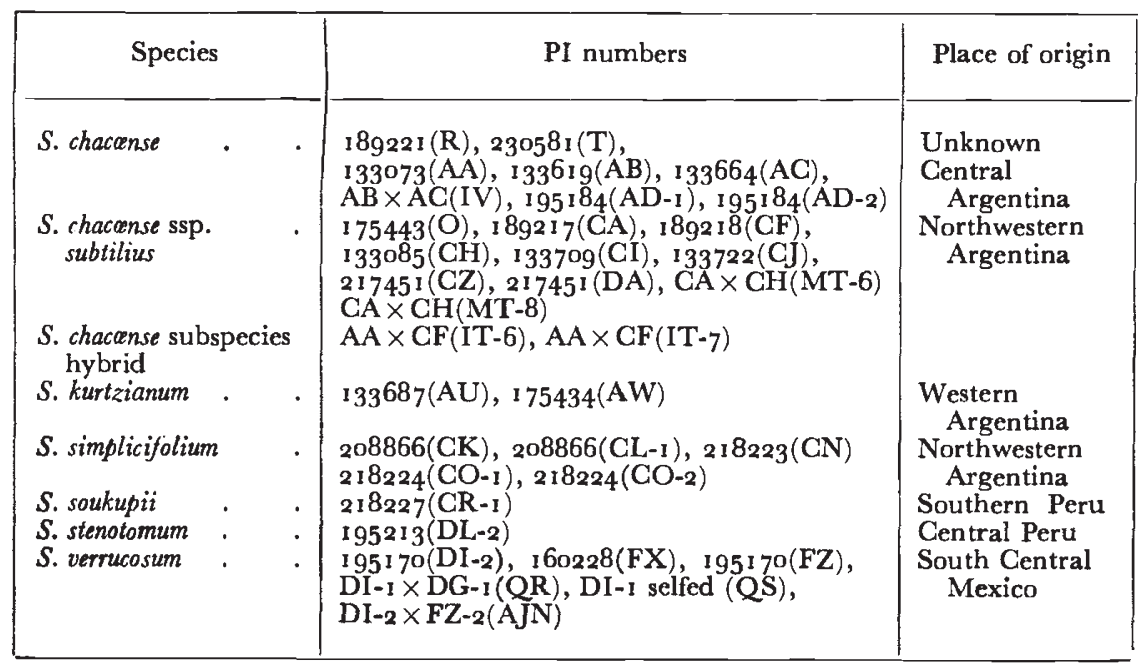

accepted $S$. verrucosum pollen tubes self-compatible clones of $S$. chaccense had been used. Crosses were carried out in the winter and spring of 1959 to determine whether this was the case. Results of self-pollination of the clones and of pollination by $S$. verrucosum are listed in table 3 .

Twenty-one of the 29 clones tested by over 20 separate self-pollinations per clone failed to set any berries at all, and the other 8 clones formed only I to 3 berries. If any of the clones tested in this way had been self-compatible, a berry set of over $5^{\circ}$ per cent. such as is obtained when $S$. verrucosum is selfed would have been expected. The low set following self-pollination could not have resulted from female sterility, for in earlier tests (Grun, 196I) cross-pollination of these same clones succeeded in over 55 per cent. of the attempts made. Therefore, the few berries formed by 8 of the clones can probably be ascribed to pseudo-incompatibility. 
Sixteen of these self-incompatible clones (table 3), agreed with the model in that they would not accept the self-compatible $S$. verrucosum pollen, while I 2 disagreed with the model and showed a set of berries.

TABLE 3

Results of self-pollination and pollination with self-compatible $\mathrm{S}$. verrucosum

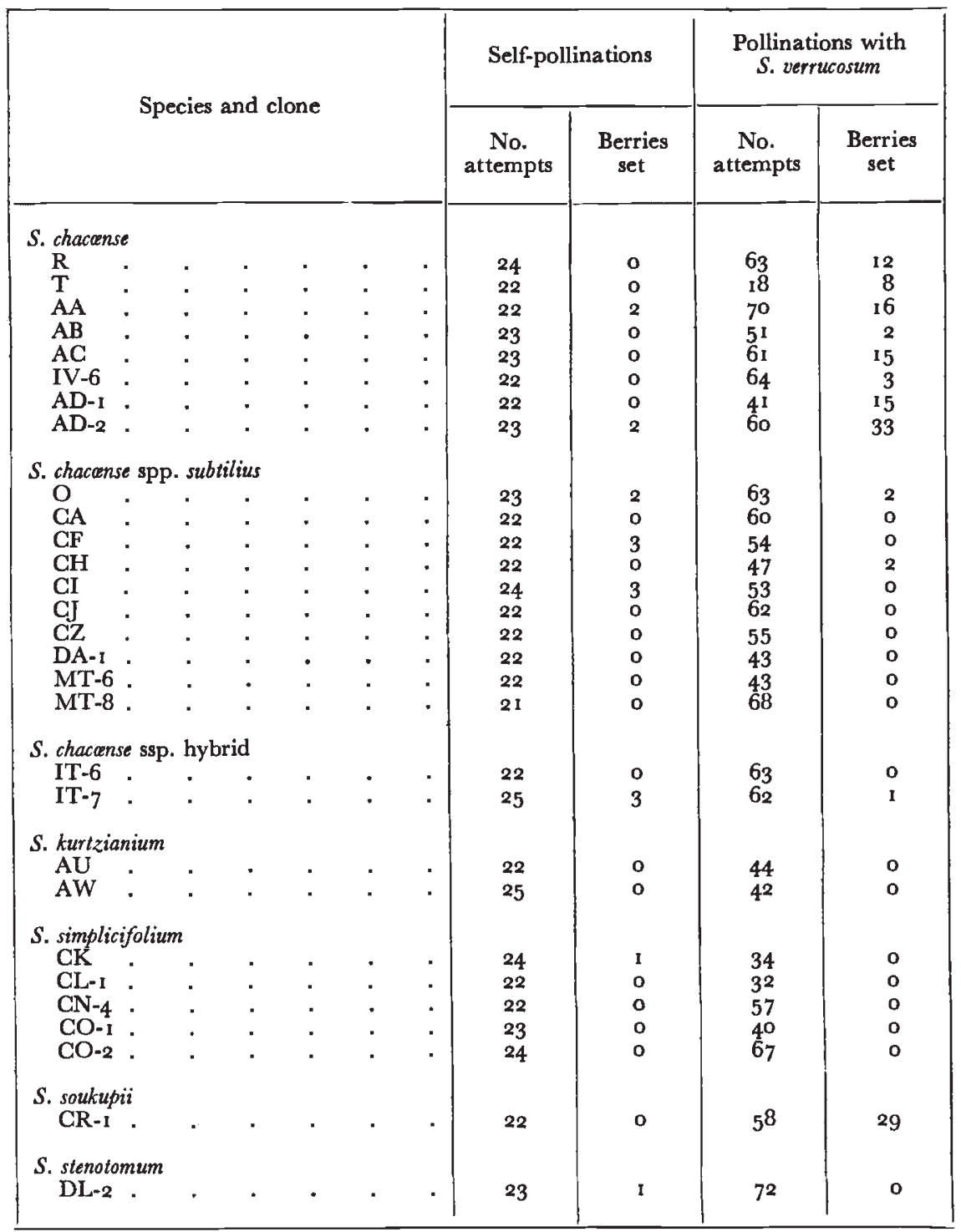

The presence or absence of pseudo-compatibility did not play any role in this regard, since 4 of the pseudo-compatibles would accept $S$. verrucosum pollen, and 4 would not. There was no particular indication that the pollen of the 6 separate lots of $S$. verrucosum used in these crosses 
differed in effectiveness so that their separate data are summed in the table. Among the I2 self-incompatible clones that did set berries with $S$. verrucosum pollen, however, there were large differences, the per cent. set of different clones ranging from 2 per cent. to over 50 per cent. with a mean of 23 per cent. The difference in per cent. berry set of plants $\mathrm{AB}$ and $\mathrm{AD}-2$, to take two extreme examples, is significant with a $\mathrm{P}$ value of less than $\mathrm{I} \times 1 \mathrm{IO}^{-8}$.

\section{DISCUSSION}

The primary purpose of this study was to determine whether the unidirectional barrier to crossing of self-compatible with self-incompatible plants operates between species of Solanum. In 6 of the tests made the unidirectional barrier did operate. This is a confirmation of the crossing results of Garde (I 959). In I 2 tests, however, the barrier was absent, and self-incompatible styles accepted the self-compatible pollen tubes of $S$. verrucosum. These results cannot be explained, as has been done for other exceptions (Lewis and Crowe, I958) by saying that $S$. verrucosum is a recently formed self-compatible species whose genotype is primarily that of the self-incompatible forms. The fundamental nature of $S$. verrucosum as a self-compatible species is revealed by its inability to set berries on styles of the 16 other self-incompatible genotypes. These results have a direct counterpart in the variability of Nicotiana alata (Anderson and DeWinton, I93I), normal selfincompatible $\mathcal{N}$. alata being receptive to the self-compatible pollen of $\mathcal{N}$. langsdorfii, while $\mathcal{N}$. alata I 5-2 followed the unidirectional crossability pattern.

There are then different forms of self-incompatible plants, some of which accept self-compatible pollen, and some of which do not. How might these phenomena be interpreted in terms of evolution? Let us assume that from time to time self-compatible and self-incompatible populations meet in nature. A self-compatible population as a result of such a meeting would acquire genes for self-incompatibility and become more cross-pollinated. This change might result in an increase in its heterozygosity at the locale where the two forms met, but the previously self-compatible population would not become sterile or weak as a result of the meeting unless pollinating vectors were lacking. The meeting would also not affect the other populations of the selfcompatible group since they, being isolated by their self-pollination mating system, would receive the self-incompatibility genes very slowly, if at all. The overall results of the meeting on the self-compatible complex would, therefore, be minimal.

The effects on the self-incompatible complex, however, could be more serious. The increased self-compatibility would lead to selfpollination with a resulting uncovering of recessive genes deleterious in the homozygous condition. The obligate cross-pollination, moreover, would lead to a spread of the self-compatibility genes in the 
self-incompatible system, and so increase the likelihood of a general inbreeding degeneration. The self-incompatible system therefore would place a strong selection premium on any mechanism which resulted in exclusion of self-compatibility genes. It is precisely in this direction that the cross fails.

This barrier to introduction of self-compatibility genes has, however, broken down in 12 of the self-incompatible clones of Solanum tested. It seems possible that the breakdown of the barrier has occurred in the self-incompatible populations partially as a result of their geographic or ecological separation from all native self-compatible species of the genus. The self-compatible species of the Tuberarium section of Solanum in South America include $S$. brevidens, a native to South Central Chile and the Nahuel Huapi region of South Argentina, and S. etuberosum which is native to North Central Chile. The other three known self-compatible species of the section, $S$. verrucosum, $S$. morelliforme and $S$. polyadenium, are native to Central America (Hawkes, I956). The biotypes of the present study which accepted $S$. verrucosum pollen include $S$. chaccense from Central Argentina, one clone from North-western Argentina, and a clone of $S$. soukupii from Southern Peru. These all, therefore, lie outside of the range of their self-compatible relatives. The result of such separation would be that an internal mechanism operating against introduction of self-compatibility genes would no longer have a selective advantage. Selection for some other character could have resulted, as a by-product of pleiotropy or linkage, in loss of the unused barrier. An alternative, though perhaps unlikely, possibility is that these forms have never come into contact with selfcompatible species of Solanum and so have not been under any selection pressure to develop isolation to crossing with them. The I6 selfincompatible clones that do not accept pollen tubes of $S$. verrucosum also are outside of the range of their self-compatible relatives. We must assume, if the hypothesis being suggested is correct, that these self-incompatible forms have an unused barrier against introduction of self-compatibility genes, which they have not as yet lost.

\section{SUMMARY}

The pollen of self-compatible Solanum verrucosum will not grow down the styles of some of the self-incompatible biotypes of several diploid species of Solanum although the reciprocal crosses regularly succeed. This result is in agreement with a general model for one-way isolation between self-compatible and self-incompatible species of plants. The one-way isolation is interpreted as resulting from a strong selection pressure for barriers which keep self-compatibility genes out of the heterozygous self-incompatible complex.

The same self-compatible $S$. verrucosum pollen does grow down the styles of other equally self-incompatible biotypes. This result is in disagreement with the general model for one-way isolation. The 
biotypes which lack the one-way isolation occur outside the geographic range of self-compatible species of Solanum. Their acceptance of selfcompatible pollen tubes is interpreted as resulting from a loss due to pleiotropy or linkage of their unused barrier against introduction of genes for self-compatibility.

Acknowledgments.-We wish to express our sincere thanks to Dr R. W. Hougas and the U.S. Department of Agriculture for supplying the plant material used in this study. We are also very much indebted to Drs H. G. Baker, J. L. Brewbaker and Jens Clausen for their critical readings of the manuscript.

\section{REFERENCES}

ANDERSON, E., AND DEWINTON, D. 1931. The genetic analysis of an unusual relationship between self-sterility and self-fertility in Nicotiana. Annals Missouri Bot. Garden, 18, 97-116.

BUGK, R. W., JR. 196o. Male sterility in interspecific hybrids of Solanum. 7. Heredity, 5I, 13-14.

CLAUSEN, JENS. 1951. Stages in the Evolution of Plant Species. Cornell University Press, Ithaca, New York.

CLAUSEN, JENS, AND HIESEY, WM. M. 1958. Experimental Studies on the Nature of Species. IV. Genetic Structure of Ecological Races. Carnegie Institution of Washington Pub. 615, Washington, D.C.

EAST, E. M. 1919. Studies on self-sterility. III. Genetics, 4, 341-355.

PABERGE, A. C. 1944. Genetics of the Scapiflora section of Papaver. 7. Genet., 46, $125-149$.

Garde, N. M. 1959. Mechanisms of species isolation in tuberous Solanum. Agronomia Lusitana, 21, 19-42.

GRUN, PAUL. 1961. Early stages in the formation of internal barriers to gene exchange between diploid species of Solanum. Amer. 7. Bot., 48 . (In press.)

HARRISON, B. J., AND DARBY, L. A. 1955. Unilateral hybridization. Nature, 176, 982.

HAWKes, J. R. 1956. A revision of the tuber-bearing Solanums. Ann. Rep. Scottish Society for Research in Plant Breeding, 1956, 37-109.

KakızAKI, Y. 1930. Studies on the genetics and physiology of self- and crossincompatibility in the common cabbage (Brassica oleracea L. var. capitata L.). 7ap. F. Bot., 5, 134-208.

LEWIS, D., AND CROWE, L. K. 1958. Unilateral interspecific incompatibility in flowering plants. Heredity, 12, 233-256.

MATHER, K. 1943. Specific differences in Petunia I. Incompatibility. 7. Genet., $45,215-235$.

MCGUIRE, D. C., AND RICK, C. M. 1954. Self-incompatibility in species of Lycopersicon sect. Eriopersicon and hybrids with L. esculentum. Hilgardia, 23, 10 1-124.

NATH, P. 1942. Studies on sterility in potatoes. I. The genetics of self- and crossincompatibilities. Indian 7. Genet. and Pl. Breeding, 2, 11-36.

NATH, P. 1945. Studies on sterility in potatoes. III. Incompatibility allelomorphs. Indian 7. Genet. and Pl. Breeding, 5, 92-105.

PAL, B. P., AND NATH, P. 1942. Genetic nature of self- and cross-incompatibility in potatoes. Nature, $149,246-247$. 